Randomized Trial

\title{
1-Year Results of a Randomized Controlled Trial of Conservative Management vs. Minimally Invasive Surgical Treatment for Sacroiliac Joint Pain
}

Julius Dengler, MD, PhD1, Djaya Kools, MD², Robert Pflugmacher, MD³, Alessandro Gasbarrini, MD, Domenico Prestamburgo, MD ${ }^{5}$, Paolo Gaetani, MD ${ }^{6}$, Eddie van Eeckhoven, RPh7, Daniel Cher, MD ${ }^{8}$, and Bengt Sturesson, $\mathrm{MD}, \mathrm{PhD}^{9}$

From: ${ }^{1}$ Charité Universitaetsmedizin, Berlin, Germany; ${ }^{2}$ OnzeLieve-Vrouw Hospital, Belgium; ${ }^{3}$ University Hospital Bonn, Germany; ${ }^{4}$ Istituto Ortopedico Rizzoli di Bologna, Bologna; ${ }^{5}$ ASST Ovest Milanese

- Ospedale di Legnano, Italy; ${ }^{6}$ Policlinico S. Matteo, Italy; ${ }^{7}$ Eeckhoven bvba, Belgium; ${ }^{8} \mathrm{SI}-\mathrm{BONE}$, Inc., San Jose, CA; ${ }^{\circ}$ Aleris Hospital, Sweden

Address Correspondence: Julius Dengler, MD, PhD Department of

Neurosurgery, Charité

- Universitaetsmedizin

Berlin, Campus Virchow Klinikum, Augustenburger

Platz 1, 13353, Berlin,

Germany

E-mail:

julius.dengler@charite.de

Disclaimer: See pg. 548.

Manuscript received: 11-19-2016

Revised manuscript received: 02-10-2017

Accepted for publication: 03-08-2017

Free full manuscript: www.painphysicianjournal. com
Background: Low back pain (LBP) emanating from the sacroiliac joint (SIJ) is a common finding. Devices to fuse the SIJ are now commercially available, but high-quality evidence supporting their effectiveness is limited.

Objectives: To compare the safety and effectiveness of conservative management (CM) to minimally invasive sacroiliac joint fusion (SIJF) in patients with chronic LBP originating from the SIJ.

Study Design: Prospective, multicenter randomized controlled trial.

Setting: One hundred three adults in spine clinics with chronic LBP originating from the SIJ.

Methods: Patients were randomly assigned to CM $(n=51)$ or SIJF using triangular titanium implants $(n=52)$. CM consisted of optimization of medical therapy, individualized physiotherapy, and adequate information and reassurance as part of a multifactorial treatment. The primary outcome was the difference in change in self-rated LBP at 6 months using a 0 - 100 visual analog scale (VAS). Other effectiveness and safety endpoints, including leg pain, disability using Oswestry Disability Index (ODI), quality of life using EQ-5D, and SIJ function using active straight leg raise test (ASLR), were assessed up to 12 months.

Results: At 12 months, mean LBP improved by 41.6 VAS points in the SIJF group vs. 14.0 points in the CM group (treatment difference of 27.6 points, $P<0.0001$ ). Mean ODI improved by 25.0 points in the SIJF group vs. 8.7 points in the CM group $(P<0.0001)$. Mean improvements in leg pain and EQ-5D scores were large after SIJF and superior to those after CM. CM patients were allowed to crossover to SIJF after 6 months. Patients who crossed to surgical treatment had no pre-crossover improvement in pain and ODI scores; after crossover, improvements were as large as those originally assigned to SIJF. One case of postoperative nerve impingement occurred in the surgical group. Two SIJF patients had recurrent pain attributed to possible device loosening and one had postoperative hematoma. In the CM group, one crossover surgery patient had recurrent pain requiring a revision surgery.

Limitations: The primary limitation was lack of blinding and the subjective nature of self-assessed outcomes.

Conclusions: For patients with chronic LBP originating from the SIJ, minimally invasive SIJF with triangular titanium implants was safe and more effective than CM in relieving pain, reducing disability, and improving patient function and quality of life. Our findings will help to inform decisions regarding its use as a treatment option in this patient population.

Key words: Sacroiliac joint dysfunction, pelvic girdle pain, randomized controlled trial, quality of life, spine implants

ClinicalTrials.gov number: NCT01741025

Pain Physician 2017; 20:537-550 
ow back pain (LBP) is the most important contributor to the global health burden (1), far lahead of other pain syndromes, such as migraine, tension headache, and neck pain. In approximately $15 \%-30 \%$ of patients with chronic LBP, a significant part of the pain originates from the sacroiliac joint (SIJ) (2-4) and the SIJ may be an even more common pain source after lumbar fusion or decompressive surgery (57). Chronic SIJ pain is associated with a poor quality of life (8).

When conservative management (CM) for SIJ pain fails, interventional treatments, such as SIJ steroid injections (9) or radiofrequency ablation have been shown in some $(10,11)$, but not all studies $(12,13)$, to provide short-term pain relief. Surgical treatments have been developed for those who fail conservative or interventional therapies. Open SIJ fusion (SIJF), first reported in the 1920s $(14,15)$, has shown moderate effectiveness in case series (16-20). Due to high perioperative morbidity and prolonged recovery times, open fusion is no longer commonly performed for chronic pain (21). Recently devices for minimally invasive SIJF became available; these carry the promise of clinical improvement via permanent joint stability while minimizing perioperative morbidity. Most published literature describes the use of triangular titanium implants (TTI) placed across the SIJ through a lateral transiliac approach, with prospective case series (22-25), comparative case series (2628), and prospective trials (29-32) showing both good long-term results and superiority over both open SIJF and CM. We report here 12-month results from a multicenter randomized controlled trial comparing clinical outcomes of minimally invasive SIJF vs. CM for patients with chronic SIJ pain.

\section{Methods}

iMIA (iFuse Implant System Minimally Invasive Arthrodesis, NCT01741025) is a prospective, open-label, multicenter randomized controlled trial conducted at 9 spine centers in Europe. The study protocol was approved at all sites by ethics committees prior to first patient enrollment and all study data were $100 \%$ source-verified. The study was sponsored by the device manufacturer. There were no significant changes to the protocol after study initiation.

\section{Patient Population}

Patients with LBP originating from the SIJ were included if they met the following criteria: adults (age 21 - 70) with SIJ pain for > 6 months (or > 18 months for pregnancy-related pain), a baseline Oswestry Disability Index (ODI) (33) score of at least 30\%, a baseline LBP visual analog score (VAS) of at least 50 (0 - 100 scale), and signed study-specific consent form. The SIJ was identified as the main origin of the pain using the following criteria, all of which had to be met: 1) pain present at or close to the posterior superior iliac spine (PSIS) and the patient could point with a single finger to the location of pain (Fortin Finger Test [34]), 2) at least 3 positive findings on 5 provocative physical examination maneuvers for SIJ pain, and 3) at least $50 \%$ pain reduction on fluoroscopically guided injection of local anesthetic into the joint (SIJ block). All SIJ blocks were intraarticular (not intraligamentous) and performed through a posterior-inferior approach by the surgeon study investigators. Once the intraarticular position of the needle's tip was confirmed by injecting $0.25-0.50$ $\mathrm{mL}$ of contrast agent into the SIJ under fluoroscopy, $0.5-1.5 \mathrm{~mL}$ of local anesthetic was injected into the joint. Each therapist was free to choose a preferred local anesthetic for this intervention. Typically, $0.25 \%$ - $0.35 \%$ bupivacaine was used. Key exclusion criteria included severe LBP due to other causes, autoimmune sacroiliitis, recent pelvic trauma, spine surgery in the last 12 months, diagnosed or suspected osteoporosis, and allergy to titanium.

\section{Randomization and Masking}

Patients were assigned at random in a 1:1 ratio after eligibility and baseline assessments (see below) by study coordinators using a password-protected website. Randomization was stratified by site and pregnancy-relatedness of SIJ pain, with random block sizes of 4 or 6 . Patients and researchers were not blinded to treatment.

\section{Interventions}

$\mathrm{CM}$, derived from European guidelines (35), consisted of 1) optimization of medical therapy, 2) individualized physiotherapy (PT) at least twice per week for up to 8 weeks that focused on mobilization and stabilization exercises for control and stability, and 3) adequate information and reassurance for the patient as part of a multifactorial treatment. Cognitive behavioral therapy (CBT) was allowed but was not available at all sites. The protocol disallowed interventional procedures (e.g., SIJ steroid injections, radiofrequency ablation of the lateral branches of sacral nerve roots) during the first 6 months.

Minimally invasive SIJF was performed using tri- 
angular titanium implants (TTI, iFuse Implant System ${ }^{\circledR}$, SI-BONE, Inc., San Jose, CA, USA) as previously described (22). Patients requiring treatment of both SIJs could undergo staged procedures. TTI are designed to acutely stabilize the SIJ and the device's porous surface promotes biological bony integration and joint fusion. After surgery, patients were kept at heel-toe touchdown weight-bearing for 3 weeks, with progression to full ambulation per individual tolerance.

\section{Follow-up and Assessments}

In-clinic follow-up visits occurred at 1, 3, 6, and 12 months (follow-up continues to 2 years). Assessments included LBP and leg pain VAS, ODI, active straight leg raise test (ASLR) (36), EuroQoL-5D quality of life (37), Zung depression scale, self-rated assessments of satisfaction, desirability of having the same intervention again, global pain ratings, and walking distance. Adverse events were assessed continuously throughout follow-up. In the ASLR, the supine patient is asked to actively lift the leg $20 \mathrm{~cm}$ off the table, with ratings from 0 (no difficulty) to 5 (unable to do).

\section{Crossover}

The protocol allowed patients assigned to CM not benefitting from it for at least 6 months to crossover to surgical care after the month 6 visit was complete.

\section{Study Endpoints, Cohorts, and Statistical Analysis}

The study's primary endpoint was the change in LBP VAS score at 6 months after SIJF or the start of CM. The study's target sample size (40 per group) provided $80 \%$ power to detect a difference of 20 points in VAS SIJ pain assuming a standard deviation (SD) of 35 points. This report focuses on 12-month outcomes.

Secondary endpoints included change from baseline in the following: LBP and leg pain VAS at other time points, ASLR for the affected side, ODI, EQ-5D, Zung Depression Scale, walking distance, and adverse events. Ttests were used for single time-point comparisons across groups; repeated measures analysis of variance was used to compare responses across time. The proportion of patients achieving a 20-point improvement in VAS LBP and 15-point improvement in ODI was compared across groups using Fisher's test. Ordinal endpoints were examined using logistic or proportional odds logistic regression. Wilcoxon's test was used to compare ordinal variables. Binary variables were compared with logistic regression or a Fisher's exact test. Poisson regression was used to examine the number of adverse events per patient. Subgroup analyses were performed to determine whether the treatment effect size (difference in response between SIJF and $\mathrm{CM}$ ) varied by subgroup.

Because crossover to surgical treatment prevented assessment of 12-month responses to $\mathrm{CM}$ alone, the last-observation carry forward (LOCF) imputation method was used to estimate 12-month values for $\mathrm{CM}$ patients who crossed over. This method is commonly employed to address missing data in clinical trials (3843) and is recommended by the Cochrane group (44). An additional analysis examined the proportion of patients who achieved threshold improvements in VAS LBP and ODI as a result of the assigned treatment only. All statistical analyses were performed using R (45).

\section{Results}

\section{Enrollment}

One hundred nine patients were enrolled in 4 countries between June 2013 and May 2015 and follow-up for this report extends through October 2016. Six patients (4 assigned to CM, 2 to SIJF) withdrew prior to receiving any intervention. Four patients at one site (2 randomized to SIJF, 2 to $\mathrm{CM}$ ) were enrolled despite having inadequate acute pain relief after SIJ block. As these patients underwent study treatment, they were included in all analyses.

Mean age was 48.1 years and 75 patients $(72.8 \%)$ were women (Table 1). Approximately $1 / 3$ were current smokers. Mean SIJ pain duration was 4.7 years and SIJ pain occurred during various activities. Most $(72.8 \%)$ had undergone prior SIJ steroid injections, a minority $(16.5 \%)$ had had prior radiofrequency ablation of the sacral nerve root lateral branches, and about 1/3 (35.9\%) had undergone prior lumbar fusion, a known risk factor for SIJ pain. The baseline mean VAS LBP was slightly but not statistically significantly higher in the SIJF group vs. the CM group (77.7 vs. $73.0, P=0.0606$ ). Both groups were similar across key demographic and clinical parameters.

\section{Patient Flow}

All participating patients underwent the assigned treatment. As of 12-month follow-up, 3 and 7 patients assigned to SIJF and CM, respectively, had withdrawn from the study (Fig. 1). The 12-month follow-up rate was $92 \%$.

\section{SIJ Fusion}

For patients assigned to SIJF, mean procedure 
Table 1. Baseline characteristics of enrolled/randomized patients.

\begin{tabular}{|c|c|c|c|}
\hline & $\begin{array}{c}\mathrm{CM} \\
(\mathrm{n}=\mathbf{5 1})\end{array}$ & $\begin{array}{c}\text { SIJ Fusion } \\
(\mathbf{n}=\mathbf{5 2})\end{array}$ & $P$ value $* *$ \\
\hline Age, mean (SD) [range] & $46.7[23-69]$ & $49.4[27-70]$ & 0.2104 \\
\hline Female, N (\%) & $37(72.5 \%)$ & $38(73.1 \%)$ & 1.0000 \\
\hline Pain duration, mean (SD) [range] & $4.5[0.45-23]$ & $4.9[0.58-44]$ & 0.7765 \\
\hline Body mass index, mean (SD) [range] & $27.6[16-44]$ & $26.5[18-42]$ & 0.3545 \\
\hline \multicolumn{4}{|l|}{ Smoking, N (\%) } \\
\hline $\begin{array}{l}\text { Current } \\
\text { Former } \\
\text { Never }\end{array}$ & $\begin{array}{c}16(31.4 \%) \\
8(15.7 \%) \\
27(52.9 \%)\end{array}$ & $\begin{array}{l}23(44.2 \%) \\
14(26.9 \%) \\
15(28.8 \%)\end{array}$ & 0.0444 \\
\hline \multicolumn{4}{|l|}{ Pain syndrome } \\
\hline $\begin{array}{l}\text { Pain began in peripartum period } \\
\text { Radiates down leg } \\
\text { Pain in groin } \\
\text { Pain sitting } \\
\text { Pain rising } \\
\text { Pain walking } \\
\text { Pain climbing stairs } \\
\text { Pain descending stairs }\end{array}$ & $\begin{array}{l}3(5.9 \%) \\
40(78.4 \%) \\
36(70.6 \%) \\
38(74.5 \%) \\
40(78.4 \%) \\
42(82.4 \%) \\
41(80.4 \%) \\
29(56.9 \%)\end{array}$ & $\begin{array}{l}6(11.5 \%) \\
42(80.8 \%) \\
31(59.6 \%) \\
42(80.8 \%) \\
48(92.3 \%) \\
43(82.7 \%) \\
41(78.8 \%) \\
33(63.5 \%)\end{array}$ & $\begin{array}{l}0.4878 \\
0.8107 \\
0.3027 \\
0.4856 \\
0.0546 \\
1.0000 \\
1.0000 \\
0.5491\end{array}$ \\
\hline \multicolumn{4}{|l|}{ Prior treatment } \\
\hline Physical therapy & $27(52.9 \%)$ & $32(61.5 \%)$ & 0.4287 \\
\hline Prolotherapy & $0(0 \%)$ & $0(0 \%)$ & 1.0000 \\
\hline Steroid SIJ injections & $38(74.5 \%)$ & $37(71.2 \%)$ & 0.8253 \\
\hline Radiofrequency ablation* & $6(11.8 \%)$ & $11(21.2 \%)$ & 0.2888 \\
\hline \multicolumn{4}{|l|}{ Work status } \\
\hline $\begin{array}{l}\text { Working normal hours/type } \\
\text { Working with limitations } \\
\text { Not working due to lower back pain } \\
\text { Not working due to other reason } \\
\text { Retired }\end{array}$ & $\begin{array}{c}3(5.9 \%) \\
12(23.5 \%) \\
27(52.9 \%) \\
2(3.9 \%) \\
7(13.7 \%)\end{array}$ & $\begin{array}{c}5(9.6 \%) \\
13(25.0 \%) \\
23(44.2 \%) \\
1(1.9 \%) \\
10(19.2 \%)\end{array}$ & 0.7918 \\
\hline \multicolumn{4}{|l|}{ Ambulatory status } \\
\hline $\begin{array}{l}\text { Ambulatory without assistance } \\
\text { Ambulatory with assistance } \\
\text { Cannot walk }\end{array}$ & $\begin{array}{c}46(90.2 \%) \\
3(5.9 \%) \\
2(3.9 \%) \\
\end{array}$ & $\begin{array}{c}42(80.8 \%) \\
8(15.4 \%) \\
2(3.8 \%) \\
\end{array}$ & 0.2945 \\
\hline History of prior lumbar fusion & $19(37.3 \%)$ & $18(34.6 \%)$ & 0.8388 \\
\hline
\end{tabular}

${ }^{*}$ Radiofrequency ablation of lateral branches of sacral nerve root.

${ }^{*}$ Fisher test for nominal variables; $\mathrm{t}$ test for continuous variables.

time was 57 minutes (range 19 - 107 minutes, Table 2). Fluoroscopy time, which was not collected routinely at one center, averaged 2.3 minutes (range $1-4$ minutes). Seventeen of 52 patients assigned to SIJF underwent bilateral SIJF. In one $(1.9 \%)$ case, 4 implants were placed; in the remaining cases, 3 implants were placed. Median hospital length of stay was 3 days (range 1 - 28). One patient had a prolonged hospital stay due to acute postoperative glaucoma causing severe diminution of vision and requiring 2 eye surgeries.

\section{Conservative Management}

For patients assigned to $\mathrm{CM}$, the mean number of PT sessions was 24.8 (range 1 - 136) and 38 (74.5\%) underwent more than 15 sessions of PT (Table 3). One patient withdrew due to inability to tolerate PT.

\section{Primary Endpoint}

At 6 months, mean (SD) LBP improvement was significantly higher in the SIJF group (43.3 [25.0] points vs. baseline, $P<0.0001$ ) vs. the CM group (5.7 [24.4] points 


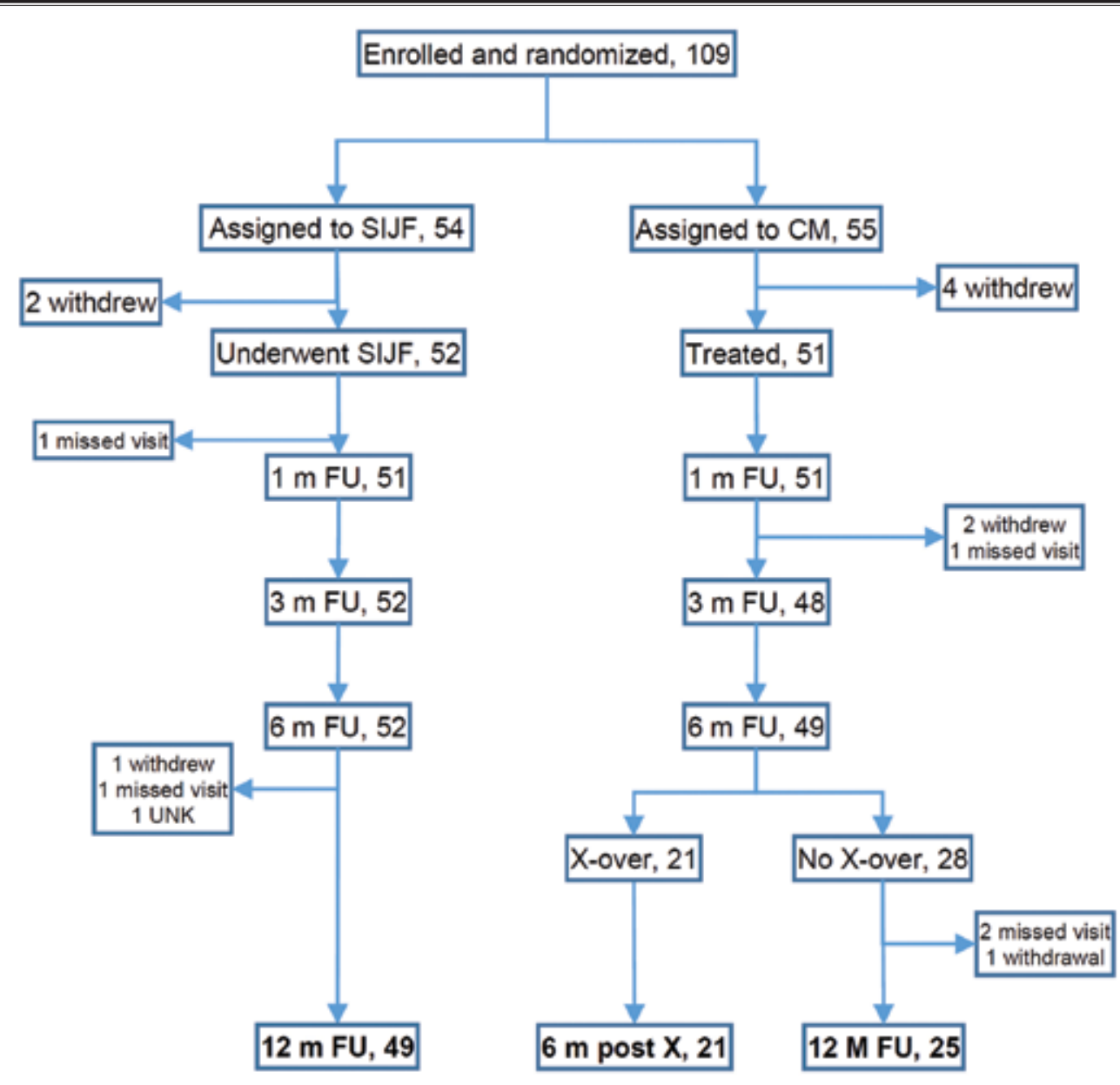

Fig. 1. Patient flow.

Table 2. Characteristics of SIJF.

\begin{tabular}{|l|c|}
\hline & $\begin{array}{c}\text { SIJF } \\
(\mathbf{n}=\mathbf{5 2})\end{array}$ \\
\hline Days from enrollment to surgery, median [range] & $18[1-82]$ \\
\hline $\begin{array}{l}\text { Number of implants, N (\%) } \\
\text { Three } \\
\text { Four }\end{array}$ & $\begin{array}{c}51(98 \%) \\
1(2 \%)\end{array}$ \\
\hline Procedure duration (min), median [range] & $54[19-107]$ \\
\hline Fluoroscopy time (min), median [range] & $2.1[1.0-4.0]$ \\
\hline Hospital length of stay (days), median [range] & $3[1-28]$ \\
\hline
\end{tabular}

*Some sites did not record fluoroscopy time
Table 3. CM interventions received during the first 6 months.

\begin{tabular}{|c|c|}
\hline & $\begin{array}{c}\text { CM } \\
(\mathbf{n}=\mathbf{5 1})\end{array}$ \\
\hline \multicolumn{2}{|c|}{ Physical therapy sessions, $\mathrm{N}(\%)$} \\
\hline $\begin{array}{l}1 \\
2 \text { to } 4 \\
5 \text { to } 10 \\
11 \text { to } 15 \\
>15\end{array}$ & $\begin{array}{c}1(2.0 \%) \\
2(3.9 \%) \\
1(2.0 \%) \\
9(17.6 \%) \\
38(74.5 \%)\end{array}$ \\
\hline \multicolumn{2}{|c|}{ Cognitive behavioral therapy sessions, $\mathrm{N}(\%)$} \\
\hline $\begin{array}{l}0 \\
1 \\
2-5 \\
6-10 \\
11-15 \\
>15\end{array}$ & $\begin{array}{c}27(52.9 \%) \\
1(2.0 \%) \\
7(13.7 \%) \\
10(19.6 \%) \\
3(5.9 \%) \\
3(5.9 \%)\end{array}$ \\
\hline
\end{tabular}




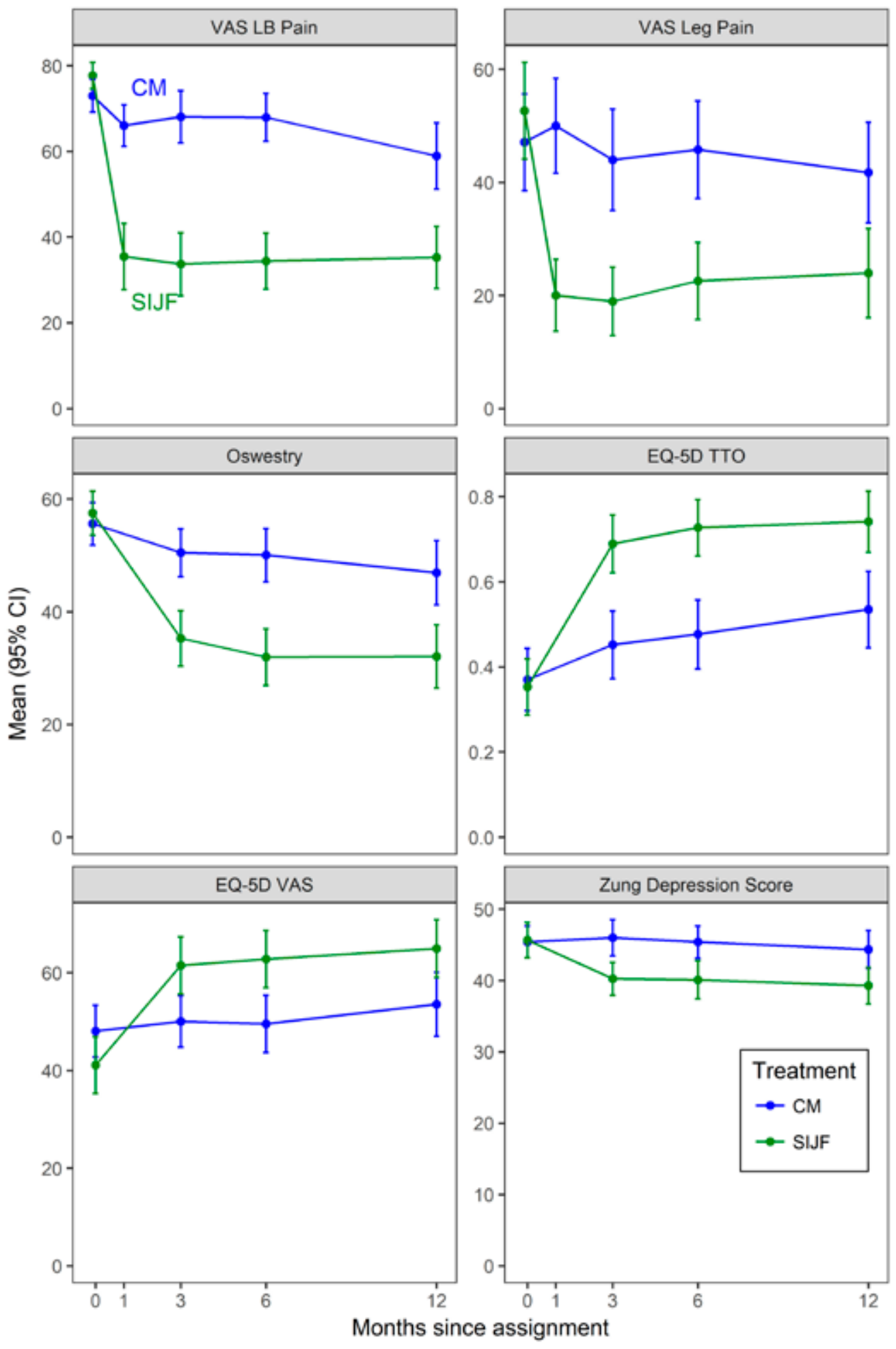

Fig. 2. Change in VAS LBP, leg pain, Oswestry Disability Index, EuroQOL-5D time trade-off (TTO) and VAS, and Zung Depression Scale scores. Blue = conservative management, green $=$ SI joint fusion. 


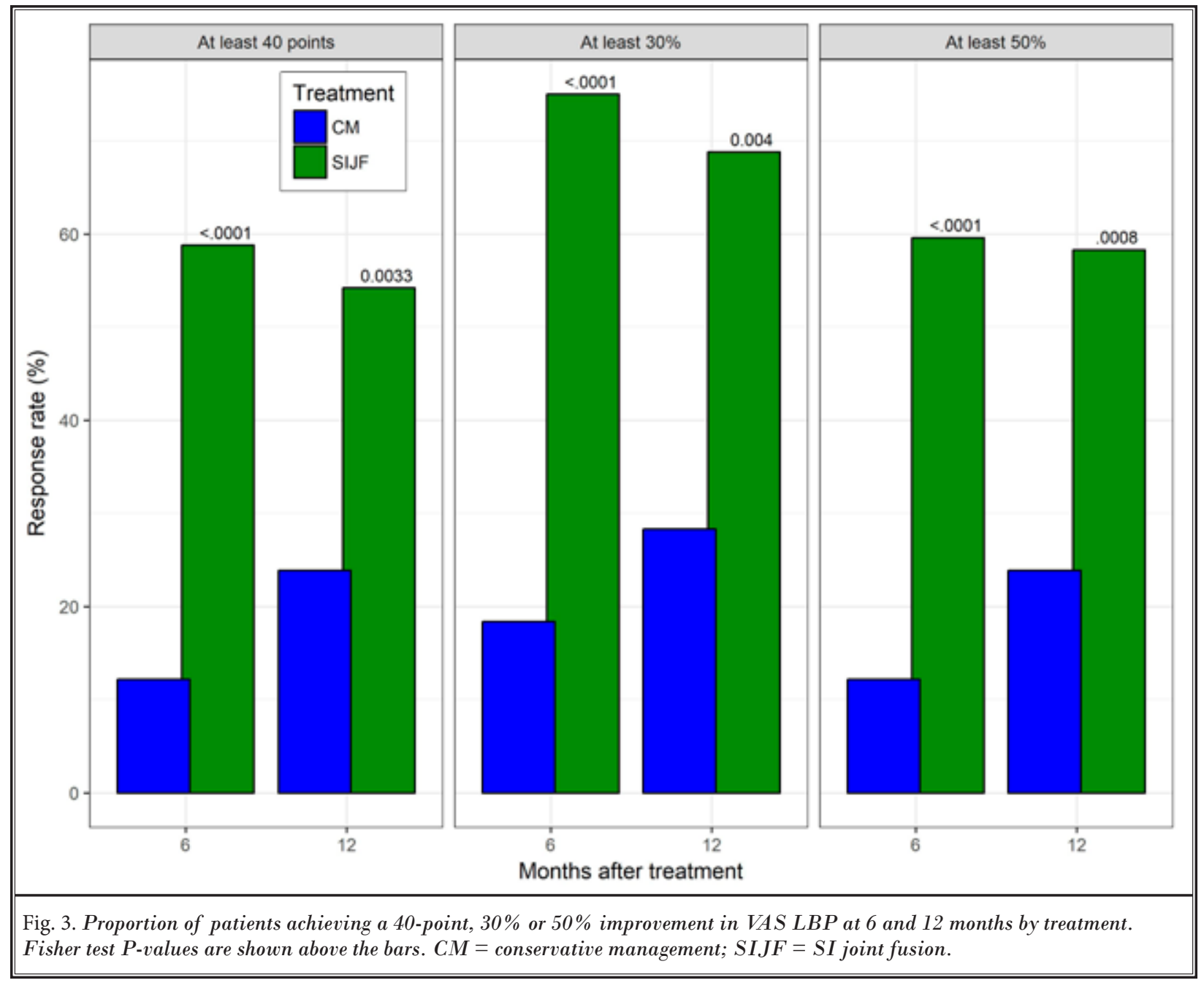

vs. baseline, $P=0.1105, P<0.0001$ for difference, Fig. 2). Repeated measures analysis of variance, which accounts for all post-treatment measurements to month 6, showed that the mean improvement in VAS LBP was 37.6 points higher in the SIJF group $(P<0.0001)$. By month $6,78.8 \%$ of patients in the SIJF group had an improvement in LBP by at least 20 VAS points, the prespecified minimal clinically important difference, compared to only $22.4 \%$ in the CM group $(P<0.0001$, a 3.5-fold difference). The proportion of patients achieving a 40-point, a 30\%, and a 50\% improvement at 6 months is shown in Fig. 3; all differences across treatments were statistically significant.

\section{Secondary Endpoints}

By month 12, mean (SD) LBP improvement was large (41.6 [27.0] points) after SIJF but small (14.0 [33.4] points) after CM, a difference of 27.6 points $(P<0.0001)$. The proportions of patients achieving the previously mentioned threshold improvements were higher in the SIJF group vs. the CM group. Similarly, 12-month improvements after SIJF in VAS leg pain, ODI, and EQ-5D were large and superior to those after CM (Table 4).

SIJ function, measured with ASLR, did not improve significantly in the $\mathrm{CM}$ group at 6 months $(0.2$ points, $P=0.3247$ ) but improved greatly in the SIJF group (2.0 points, $P<0.0001$ for both change from baseline and comparison to the CM group change, Fig. 4). The proportion of patients who could raise the affected leg with no or minimal difficulty at 6 months was $40.0 \%$ in the SIJF group and $12.5 \%$ in the CM group (Fisher $P=$ 0.0052 , a 3-fold improvement). Superior improvement in the number of positive physical examination findings was also observed $(P<0.0001)$. 
Table 4. Pain, disability, QOL, and depression scores by treatment and visit.

\begin{tabular}{|c|c|c|c|}
\hline & $\begin{array}{c}C M \\
(n=51)\end{array}$ & $\begin{array}{c}\text { SIJF } \\
(n=52)\end{array}$ & $P$-value* \\
\hline \multicolumn{4}{|c|}{ Low back pain } \\
\hline Baseline & $73.0(13.8)$ & $77.7(11.3)$ & \multirow{5}{*}{$<0.0001$} \\
\hline Month 1 & $66.0(17.7)$ & $35.4(28.4)$ & \\
\hline Month 3 & $67.5(22.3)$ & $33.6(27.2)$ & \\
\hline Month 6 & $67.8(20.3)$ & $34.4(23.9)$ & \\
\hline Month 12 & $58.9(28.2)$ & $35.2(25.5)$ & \\
\hline \multicolumn{4}{|l|}{ Leg pain } \\
\hline Baseline & $47.1(31.1)$ & $52.7(31.5)$ & \multirow{5}{*}{0.0002} \\
\hline Month 1 & $50.0(30.5)$ & $20.0(23.4)$ & \\
\hline Month 3 & $45.6(32.5)$ & $19.0(22.2)$ & \\
\hline Month 6 & $46.5(31.4)$ & $22.6(25.1)$ & \\
\hline Month 12 & $41.7(32.4)$ & $24.0(27.8)$ & \\
\hline \multicolumn{4}{|l|}{ ODI } \\
\hline Baseline & $55.6(13.7)$ & $57.5(14.4)$ & \multirow{4}{*}{$<0.0001$} \\
\hline Month 3 & $50.6(15.5)$ & $35.1(18.3)$ & \\
\hline Month 6 & $50.2(17.2)$ & $32.0(18.4)$ & \\
\hline Month 12 & $46.9(20.8)$ & $32.1(19.9)$ & \\
\hline \multicolumn{4}{|c|}{ EQ-5D TTO } \\
\hline Baseline & $0.37(0.27)$ & $0.35(0.24)$ & \multirow{4}{*}{0.0009} \\
\hline Month 3 & $0.46(0.29)$ & $0.69(0.25)$ & \\
\hline Month 6 & $0.48(0.30)$ & $0.73(0.24)$ & \\
\hline Month 12 & $0.54(0.33)$ & $0.74(0.25)$ & \\
\hline \multicolumn{4}{|c|}{ EQ-5D VAS } \\
\hline Baseline & $41.1(21.3)$ & $48.1(19.3)$ & \multirow{4}{*}{0.0005} \\
\hline Month 3 & $61.5(21.6)$ & $50.2(19.6)$ & \\
\hline Month 6 & $62.8(21.5)$ & $49.8(21.6)$ & \\
\hline Month 12 & $64.9(20.9)$ & $53.5(23.8)$ & \\
\hline \multicolumn{4}{|c|}{ Zung Depression Scale } \\
\hline Baseline & $45.4(8.0)$ & $45.7(9.1)$ & \multirow{4}{*}{0.0035} \\
\hline Month 3 & $46.1(9.4)$ & $40.2(8.6)$ & \\
\hline Month 6 & $45.4(8.3)$ & $40.1(9.8)$ & \\
\hline Month 12 & $44.4(9.6)$ & $39.6(9.2)$ & \\
\hline
\end{tabular}

Several additional outcomes were superior in the SIJF group compared to CM, including self-reported walking distance $(P=0.0177)$, global comparison to baseline $(P<0.0001)$, satisfaction levels $(P<0.0001)$, and desirability of having the same treatment again ( $P$ $=0.0001$, Table 5, Fig. 5). Ambulatory status at month 6 was similar across groups $(P=0.6082)$. The proportion working normal hours at month 6 was higher (but not statistically significant) in the SIJF group (23.1\% for SIJF vs. $12.2 \%$ for $C M, P=0.0851)$. At month 12 , work status in the SIJF group was significantly improved compared to baseline $(P=0.0118)$.

\section{Crossover}

According to the study protocol, patients assigned to $\mathrm{CM}$ who did not derive benefit from it for at least 6 months were allowed to crossover to SIJF or any other surgical or interventional procedure after the 6-month visit was complete. Of the $49 \mathrm{CM}$ patients still participating at 6 months, $21(43 \%)$ crossed over to surgical treatment. Compared to CM patients who did not crossover, crossover patients had higher 6-month LBP scores (76.7 vs. $61.0, P=0.0033)$, higher leg pain scores $(57.8$ vs. $38.0, P=0.0260$ ), higher ODI scores (59.0 vs. $43.6, P$ $=0.0006$ ), and lower QOL scores (EQ-5D TTO 0.27 vs. $0.63, P<0.0001)$. CM patients who crossed over had no improvement in any of these scores between baseline and 6 months. Other than having shorter pain duration (2.3 vs. 6.1 years, $P=0.0055$ ), patients who crossed over showed no distinct clinical or demographic patterns. Six months after crossover, all pain, disability, and quality of life parameters improved nearly identically to those among patients originally assigned to SIJF (Table 6). Some CM patients who did not crossover to SIJF showed benefits after month 6 . By month 12, 14 non-crossing patients ( $27 \%$ of all patients originally assigned to CM) had at least a 20-point improvement in VAS back pain and $13(25 \%)$ had at least a 15-point improvement in $\mathrm{ODI}$ as a result of $\mathrm{CM}$ alone. For patients assigned to SIJF, these proportions were $69 \%$ and $65 \%$, respectively $(P<0.0001$ for both comparisons vs. CM).

\section{Subgroup Analyses}

Prespecified statistical models exploring interaction effects (underlying condition, study center, other factors) did not show any material difference in treatment effect size. Similarly, preplanned subgroup analysis for the primary endpoint, which included pain related to pregnancy or not, history of prior lumbar fusion or not, and unilateral vs. bilateral SIJ pain at baseline, showed similar responses in subgroups. Additional subgroup analysis, including gender, age (by quartiles), body mass index (BMI) category, pain duration (by quartiles), and whether taking strong opioids at baseline, also showed no differences in responses between SIJF and CM within subgroups.

\section{Adverse Events}

Within 6 months (200 days) of initial treatment, there were 34 reported adverse events, 17 in each group. By month 6, the mean number of events per patient was 0.33 ( $P=0.9549$ for rate difference). Looking at all reported events (mean of 21.5 months of followup per group), there were 25 events rated severe in the SIJF group and 24 in the CM group, of which most were unrelated to the device or procedure. Severe device- or 

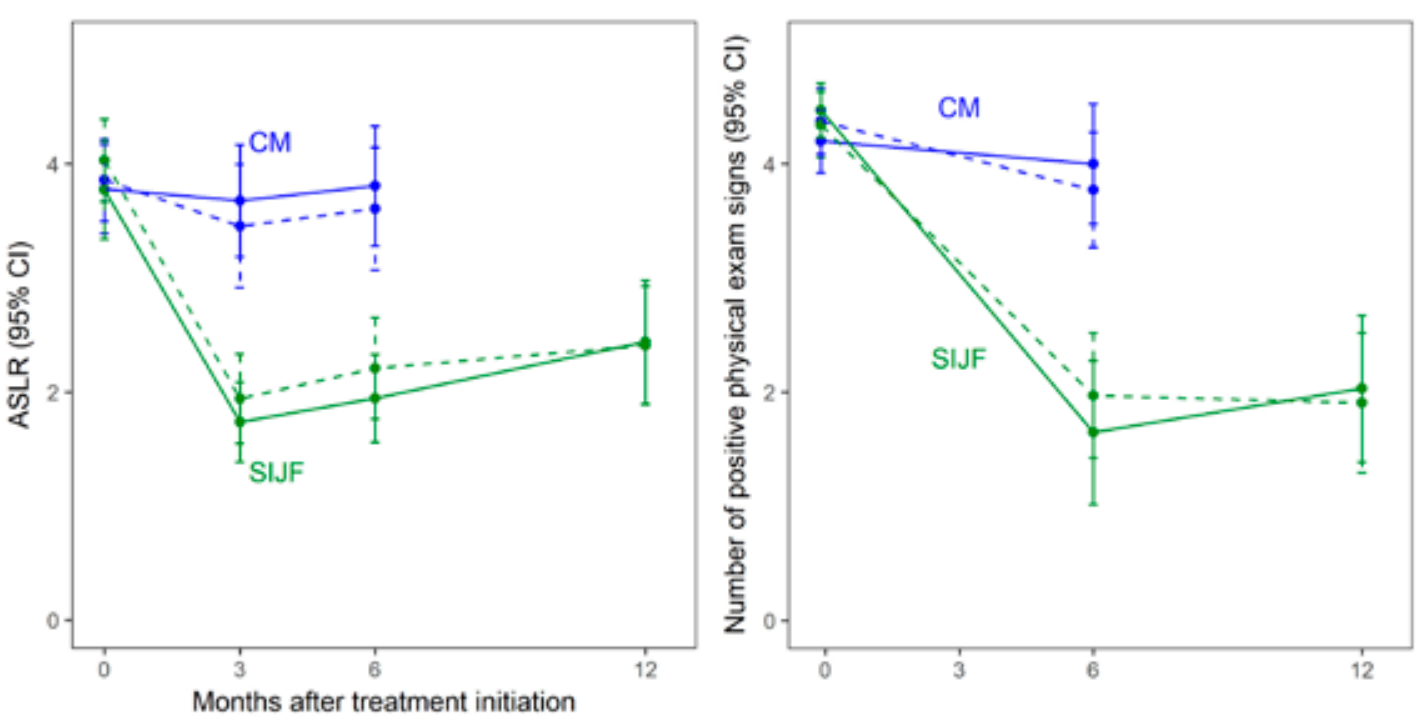

Fig. 4. Improvement in functional test (active straight leg raise test) by treatment and time (left) and number of positive physical examination signs (right).

Table 5. Other study outcomes.

\begin{tabular}{|c|c|c|c|c|}
\hline & CM* & SIJF* & SIJF** & $P$-value**** \\
\hline \multicolumn{5}{|l|}{ Walking distance } \\
\hline $\begin{array}{l}<100 \mathrm{~m} \\
100-500 \mathrm{~m} \\
0.5-1 \mathrm{~km} \\
>1 \mathrm{~km}\end{array}$ & $\begin{array}{l}12(24.5 \%) \\
17(34.7 \%) \\
10(20.4 \%) \\
10(20.4 \%) \\
\end{array}$ & $\begin{array}{c}7(13.5 \%) \\
12(23.1 \%) \\
13(25.0 \%) \\
20(38.5 \%) \\
\end{array}$ & $\begin{array}{c}4(8.3 \%) \\
8(16.7 \%) \\
15(31.2 \%) \\
21(43.8 \%) \\
\end{array}$ & 0.017721 \\
\hline \multicolumn{5}{|l|}{ Work status } \\
\hline $\begin{array}{l}\text { Not working due to lower back pain } \\
\text { Not working due to other reason } \\
\text { Retired } \\
\text { Working with limitations } \\
\text { Working normal hours/type }\end{array}$ & $\begin{array}{c}28(57.1 \%) \\
0(0.0 \%) \\
5(10.2 \%) \\
10(20.4 \%) \\
6(12.2 \%)\end{array}$ & $\begin{array}{c}21(40.4 \%) \\
2(3.8 \%) \\
11(21.2 \%) \\
6(11.5 \%) \\
12(23.1 \%)\end{array}$ & $\begin{aligned} 15 & (31.2 \%) \\
4 & (8.3 \%) \\
10 & (20.8 \%) \\
11 & (22.9 \%) \\
8 & (16.7 \%)\end{aligned}$ & 0.0851 \\
\hline \multicolumn{5}{|l|}{ Walking status } \\
\hline $\begin{array}{l}\text { Ambulatory without assistance } \\
\text { Ambulatory with assistance } \\
\text { Cannot walk }\end{array}$ & $\begin{array}{l}45(91.8 \%) \\
2(4.1 \%) \\
2(4.1 \%)\end{array}$ & $\begin{array}{c}46(88.5 \%) \\
5(9.6 \%) \\
1(1.9 \%)\end{array}$ & $\begin{array}{c}42(87.5 \%) \\
5(10.4 \%) \\
1(2.1 \%)\end{array}$ & 0.7420 \\
\hline \multicolumn{5}{|l|}{ Level of satisfaction } \\
\hline $\begin{array}{l}\text { Very satisfied } \\
\text { Somewhat satisfied } \\
\text { Somewhat dissatisfied } \\
\text { Very dissatisfied }\end{array}$ & $\begin{array}{c}9(18.4 \%) \\
15(30.6 \%) \\
23(46.9 \%) \\
2(4.1 \%)\end{array}$ & $\begin{array}{c}28(53.8 \%) \\
19(36.5 \%) \\
3(5.8 \%) \\
2(3.8 \%) \\
\end{array}$ & $\begin{array}{c}25(52.1 \%) \\
18(37.5 \%) \\
5(10.4 \%) \\
0(0.0 \%)\end{array}$ & $<0.0001$ \\
\hline \multicolumn{5}{|c|}{ Desirability of having assigned treatment again } \\
\hline $\begin{array}{l}\text { Definitely not } \\
\text { Don't know } \\
\text { Definitely yes }\end{array}$ & $\begin{array}{l}10(20.4 \%) \\
18(36.7 \%) \\
21(42.9 \%)\end{array}$ & $\begin{array}{c}2(3.8 \%) \\
8(15.4 \%) \\
42(80.8 \%) \\
\end{array}$ & $\begin{array}{c}1(2.1 \%) \\
11(22.9 \%) \\
36(75.0 \%)\end{array}$ & 0.0001 \\
\hline \multicolumn{5}{|l|}{ Global comparison to baseline } \\
\hline $\begin{array}{l}\text { Worse } \\
\text { Same } \\
\text { Better } \\
\text { Much better }\end{array}$ & $\begin{array}{c}16(32.7 \%) \\
17(34.7 \%) \\
12(24.5 \%) \\
4(8.2 \%)\end{array}$ & $\begin{array}{c}3(5.8 \%) \\
6(11.5 \%) \\
23(44.2 \%) \\
20(38.5 \%)\end{array}$ & $\begin{array}{c}3(6.2 \%) \\
6(12.5 \%) \\
21(43.8 \%) \\
18(37.5 \%)\end{array}$ & $<0.0001$ \\
\hline
\end{tabular}

${ }^{\star} 6$ month; ${ }^{* *} 12$ month; ${ }^{* * *}$ Comparison of 6 -month values 


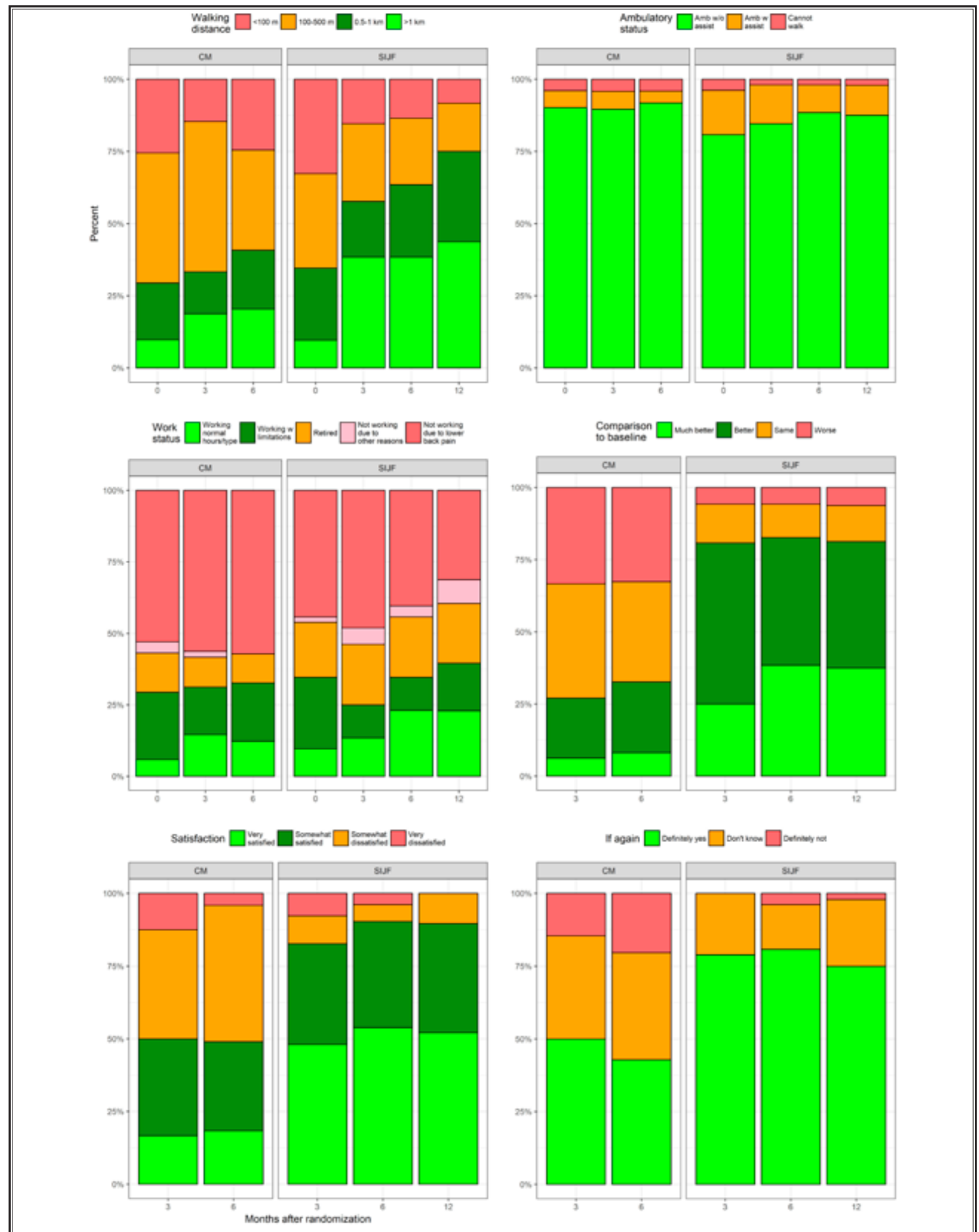

Fig. 5. Improvement in walking distance, ambulatory status, work status, comparison to baseline, satisfaction and desirability of having surgery again by treatment and follow-up visit. Small numbers within each bar are the number of observations. 
procedure-related events included the following: In the SIJF group, 2 patients experienced recurrent ( $\sim 1$ year) SIJ pain attributed to possible device loosening in the sacrum (one of these patients had a possible labral tear of the hip and both had experienced a fall on the buttocks); one patient had new onset leg pain postoperatively related to implant malposition; and one patient had a postoperative hematoma. In the CM group, one patient had SIJ pain attributed to device loosening after a crossover procedure and eventually underwent a revision surgery, and one patient had hematoma after a crossover procedure.

\section{Discussion}

The main result of our randomized controlled trial is that for patients with chronic LBP originating from the SIJ, continued CM was associated with no clinically relevant improvement in LBP on average, whereas minimally invasive SIJF resulted in large, clinically important and statistically significant improvements. Similar findings were observed for other endpoints, including physical function, quality of life scores, and several additional related outcomes. While some patients assigned to $\mathrm{CM}$ showed a clinical benefit (pain rating decrease by 20 or more points), the proportion was substantially lower than in the SIJF group $(22.4 \%$ vs. $78.8 \%, P<0.0001)$. For SIJF patients, improvements appeared early (evident by one month after fusion) and persisted at one year. Quality of life, measured with EQ$5 D$, showed improvement after SIJF (but not CM) that was at least as large (or larger) than that observed in the Swedish Spine registry of several different spine surgeries (46). Preplanned subgroup analyses showed similar responses to SIJF across all groups.

Our results are consistent with a similarly designed randomized clinical trial of the same patient population conducted in the US (29), a concurrent large prospective multicenter clinical trial in the US (30), and several case series $(22-25,47,48)$. Our study extends these findings by 1) showing superior responses in both functional tests (ASLR and physical examination findings) as well as self-reported walking distance, both of which have not been previously reported, and 2) estimating treatment effect sizes at one year. Our study included patients with chronic SIJ dysfunction diagnosed by a standard approach (history, physical examination, and diagnostic block), supporting generalizability for the enrolled population. Two study investigators (comprising 19 of 103 patients) had performed more than 15 cases prior to study start; the remaining 7 investigators had per-
Table 6. Mean improvement 6 months after SIJF in parameters comparing those who were originally assigned to SIJF vs. those who crossed over from CM to SIJF.

\begin{tabular}{|l|c|c|}
\hline & $\begin{array}{c}\text { Originally Assigned to SIJF } \\
(\mathbf{n}=\mathbf{5 2})\end{array}$ & $\begin{array}{c}\text { Crossed Over } \\
(\mathbf{n}=\mathbf{2 1})\end{array}$ \\
\hline VAS $^{\star}$ low back & 43.3 & 38.9 \\
\hline VAS leg & 30.1 & 31.9 \\
\hline ODI & 25.5 & 25.7 \\
\hline EQ-5D TTO & 0.37 & 0.35 \\
\hline EQ-5D VAS & 22 & 18 \\
\hline
\end{tabular}

*VAS: visual analog scale; ODI: Oswestry Disability Index; EQ-5D: EuroQOL-5D; TTO: time trade-off

formed $<10$ procedures prior to study start. Our data suggest that SIJF provides benefit at low risk even when performed by relatively inexperienced (albeit skilled) surgeons.

In our study, the control treatment, CM, consisted primarily of intensive physiotherapy as directed by European treatment guidelines for pelvic girdle pain (35). The previously reported US randomized trial's control treatment included intraarticular SIJ steroid injections (for which there are no published randomized trials) and radiofrequency ablation of the lateral branches of the sacral nerve roots. Interestingly, the effect size (difference between surgical and control treatments) was nearly identical between our study and the US randomized trial: for low back pain (SIJ pain) 38 points and for ODI 18 points.

When comparing CM patients who crossed over to surgery after month 6 to those who did not crossover, we found higher levels of pain and disability and lower quality of life scores in the former group. All crossing patients underwent the same SIJF procedure and postcrossover improvements in all parameters were nearly identical to those in the group originally assigned to SIJF. These findings can be interpreted as an internal validation of the study procedure's efficacy.

A modest proportion $(25 \%-27 \%)$ of CM patients did not crossover but achieved threshold improvements in LBP or ODI by month 12. Although this rate was lower than in the surgical group $(65 \%-69 \%)$, it suggests that some patients may benefit from individualized physiotherapy.

Surgical revision, an important clinical outcome, occurred in only 2 SIJF patients to date: one case of implant revision and one procedure to address a postoperative hematoma. Placement of devices too close to a sacral nerve root is a known but uncommon risk (1\%) after SIJF (49). The overall implant revision rate $(3.6 \%$ at 
4 years) (49) is low compared to standard open surgical procedures in the spine $(50,51)$. A small number of patients had recurrent pain attributed to possible implant loosening seen on computed tomography (CT) scan. No unanticipated adverse events occurred. On balance, the benefits attributable to SIJF appeared to outweigh the risks.

Our study has several limitations. As the intervention was not blinded, it is possible that extraneous factors associated with SIJF may have contributed to greater responses in the SIJF group. The purpose of our study was not to estimate the proportion of the surgery effect attributable to the device (as would a sham study) but rather to estimate the increment in relief of pain, disability, and poor quality of life potentially observable in standard practice. Furthermore, while the diagnostic algorithm used was standardized, it is possible that some patients had other pathologies contributing to LBP, which could have limited the degree of response to SIJF. Third, non-surgical care, patterned after European guidelines for pelvic girdle pain, may have varied across centers. Physical therapy may be helpful in postpartum pelvic girdle pain (52), but the target population in our study was different. Fourth, the fact that a substantial number of patients undergoing CM crossed over to surgery after 6 months prevented direct effect size calculations after the month 6 visit. A commonly used imputation method was used to impute missing values in these patients. Use of the method was reasonable given that patients who crossed had no improvement in measured parameters at month 6. Moreover, the persistent improvement in all parameters at month 12 , combined with the very small improvements in the $\mathrm{CM}$ group at 6 months, provide reassurance regarding longer-term outcomes. We look forward to reporting longer-term (2-year) follow-up in the SIJF cohort.

\section{Conclusion}

In summary, 12-month data from our randomized surgery vs. non-surgical clinical trial show that minimally invasive SIJF with TTIs provided superior pain, disability, function, and quality of life outcomes compared to CM. Improvements persisted in the SIJF group at month 12 Our findings suggest that minimally invasive SIJF may be a reasonable option for patients with SIJ pain not responsive to non-surgical care.

\section{Disclosures}

The study reported herein was sponsored by SIBONE, the device's manufacturer. The sponsor provided tools for electronic data capture. Study authors' practices or universities were paid by the sponsor to support the research (supplies, personnel, etc.). The sponsor helped to perform data monitoring, source verification, cleaning and statistical analysis. All statistical analysis was reviewed by study authors. This is standard practice in industry-sponsored studies. The sponsor prepared an initial draft of the study manuscript. These are all standard practice in industry-sponsored studies.

Daniel Cher is an SI-BONE employee. Eddie van Eeckhoven is a clinical trials and regulatory consultant to SI-BONE. Bengt Sturesson, Djaya Kools and Robert Pflugmacher are paid consultants to SI-BONE. Their activities include primarily teaching of the procedure and the basic biology of the sacroiliac joint. No author received direct payment for the study. No author has received any reimbursement or honorarium in any other manner.

\section{References}

1. Vos T, Flaxman AD, Naghavi M, Lozano R, Michaud C, Ezzati M, Shibuya K, Salomon JA, Abdalla S, Aboyans V, Abraham J, Ackerman I, Aggarwal R, Ahn SY, Ali MK, Alvarado M, Anderson HR, Anderson LM, Andrews KG, Atkinson C, Baddour LM, Bahalim AN, Barker-Collo S, Barrero LH, Bartels DH, Basáñez M-G, Baxter A, Bell ML, Benjamin EJ, Bennett $D$, Bernabé $E$, Bhalla $K$, Bhandari B, Bikbov B, Bin Abdulhak A, Birbeck G, Black JA, Blencowe $H$, Blore JD, Blyth $F$, Bolliger I, Bonaventure A, Boufous S, Bourne R, Boussinesq M, Braithwaite $T$,
Brayne C, Bridgett L, Brooker S, Brooks $P$, Brugha TS, Bryan-Hancock C, Bucello C, Buchbinder R, Buckle G, Budke CM, Burch M, Burney P, Burstein R, Calabria B, Campbell B, Canter CE, Carabin H, Carapetis J, Carmona L, Cella C, Charlson F, Chen H, Cheng AT-A, Chou D, Chugh SS, Coffeng LE, Colan SD, Colquhoun $\mathrm{S}$, Colson KE, Condon J, Connor MD, Cooper LT, Corriere M, Cortinovis M, de Vaccaro KC, Couser W, Cowie BC, Criqui $\mathrm{MH}$, Cross M, Dabhadkar KC, Dahiya $M$, Dahodwala N, Damsere-Derry J, Danaei G, Davis A, De Leo D, Degenhardt L, Dellavalle R, Delossantos A, Denen- berg J, Derrett S, Des Jarlais DC, Dharmaratne SD, Dherani M, Diaz-Torne C, Dolk H, Dorsey ER, Driscoll T, Duber H, Ebel B, Edmond K, Elbaz A, Ali SE, Erskine $H$, Erwin PJ, Espindola P, Ewoigbokhan SE, Farzadfar F, Feigin V, Felson DT, Ferrari A, Ferri CP, Fèvre EM, Finucane MM, Flaxman S, Flood L, Foreman K, Forouzanfar $\mathrm{MH}$, Fowkes FG, Franklin R, Fransen M, Freeman MK, Gabbe B), Gabriel SE, Gakidou E, Ganatra HA, Garcia B, Gaspari F, Gillum RF, Gmel G, Gosselin R, Grainger R, Groeger J, Guillemin F, Gunnell D, Gupta R, Haagsma J, Hagan H, Halasa YA, Hall W, Haring 
D, Haro JM, Harrison JE, Havmoeller R, Hay RJ, Higashi H, Hill C, Hoen B, Hoffman H, Hotez PJ, Hoy D, Huang J, Ibeanusi SE, Jacobsen KH, James SL, Jarvis D, Jasrasaria R, Jayaraman S, Johns $\mathrm{N}$, Jonas JB, Karthikeyan G, Kassebaum N, Kawakami N, Keren A, Khoo JP, King $\mathrm{CH}$, Knowlton LM, Kobusingye $\mathrm{O}$, Koranteng $A$, Krishnamurthi $R$, Lalloo $R$, Laslett LL, Lathlean T, Leasher JL, Lee YY, Leigh J, Lim SS, Limb E, Lin JK, Lipnick M, Lipshultz SE, Liu W, Loane M, Ohno SL, Lyons R, Ma J, Mabweijano J, Maclntyre MF, Malekzadeh R, Mallinger L, Manivannan S, Marcenes W, March L, Margolis DJ, Marks GB, Marks R, Matsumori A, Matzopoulos R, Mayosi BM, McAnulty JH, McDermott MM, McGill N, McGrath J, Medina-Mora ME, Meltzer M, Mensah GA, Merriman TR, Meyer AC, Miglioli V, Miller M, Miller TR, Mitchell PB, Mocumbi AO, Moffitt TE, Mokdad AA, Monasta L, Montico M, Moradi-Lakeh M, Moran A, Morawska L, Mori R, Murdoch ME, Mwaniki MK, Naidoo K, Nair MN, Naldi L, Narayan KM, Nelson PK, Nelson RG, Nevitt MC, Newton CR, Nolte $S$, Norman P, Norman R, O'Donnell M, O'Hanlon S, Olives C, Omer SB, Ortblad K, Osborne R, Ozgediz D, Page A, Pahari B, Pandian JD, Rivero AP, Patten SB, Pearce N, Padilla RP, Perez-Ruiz F, Perico N, Pesudovs K, Phillips D, Phillips MR, Pierce K, Pion S, Polanczyk GV, Polinder S, Pope CA 3rd, Popova S, Porrini E, Pourmalek $F$, Prince $M$, Pullan RL, Ramaiah KD, Ranganathan D, Razavi $H$, Regan $M$, Rehm JT, Rein DB, Remuzzi G, Richardson K, Rivara FP, Roberts T, Robinson C, De Leòn FR, Ronfani L, Room R, Rosenfeld LC, Rushton L, Sacco RL, Saha S, Sampson U, Sanchez-Riera L, Sanman E, Schwebel DC, Scott JG, Segui-Gomez $M$, Shahraz S, Shepard DS, Shin H, Shivakoti $R$, Singh $D$, Singh GM, Singh JA, Singleton J, Sleet DA, Sliwa K, Smith E, Smith JL, Stapelberg NJ, Steer A, Steiner T, Stolk WA, Stovner LJ, Sudfeld C, Syed S, Tamburlini G, Tavakkoli M, Taylor HR, Taylor JA, Taylor WJ, Thomas B, Thomson WM, Thurston GD, Tleyjeh IM, Tonelli M, Towbin JA, Truelsen T, Tsilimbaris MK, Ubeda C, Undurraga EA, van der Werf MJ, van Os J, Vavilala MS, Venketasubramanian N, Wang $M$, Wang W, Watt K, Weatherall DJ, Weinstock MA, Weintraub R, Weisskopf MG, Weissman MM, White RA, Whiteford $\mathrm{H}$, Wiersma ST, Wilkinson JD, Williams HC, Williams SR, Witt E, Wolfe F, Woolf $A D$, Wulf S, Yeh PH, Zaidi AK, Zheng ZJ, Zonies D, Lopez AD, Murray CJ, AlMaz- roa MA, Memish ZA. Years lived with disability (YLDs) for 1160 sequelae of 289 diseases and injuries 1990-2010: A systematic analysis for the Global Burden of Disease Study 2010. Lancet 2012; 380:2163-2196.

2. Sembrano JN, Polly DW. How often is low back pain not coming from the back? Spine 2009; 34:E27-E32.

3. Bernard TN, Kirkaldy-Willis WH. Recognizing specific characteristics of nonspecific low back pain. Clin Orthop 1987; 266-28o.

4. Schwarzer AC. The sacroiliac joint in chronic low back pain. Spine 1995: 20:31-7.

5. DePalma MJ, Ketchum JM, Saullo TR. Etiology of chronic low back pain in patients having undergone lumbar fusion. Pain Med 2011; 12:732-739.

6. Liliang P-C, Lu K, Liang C-L, Tsai Y-D, Wang K-W, Chen H-J. Sacroiliac joint pain after lumbar and lumbosacral fusion: Findings using dual sacroiliac joint blocks. Pain Med Malden Mass 2011; 12:565-570.

7. Schomacher M, Kunhardt O, Koeppen D, Moskopp D, Kienapfel H, Kroppenstedt S, Cabraja M. Transient sacroiliac joint-related pain is a common problem following lumbar decompressive surgery without instrumentation. Clin Neurol Neurosurg 2015; 139:81-85.

8. Cher D, Polly D, Berven S. Sacroiliac Joint pain: Burden of disease. Med Devices Evid Res 2014; 7:73-81.

9. Luukkainen $R$, Nissilä $M$, Asikainen $E$, Sanila $M$, Lehtinen $K$, Alanaatu A, Kautiainen $\mathrm{H}$. Periarticular corticosteroid treatment of the sacroiliac joint in patients with seronegative spondylarthropathy. Clin Exp Rheumatol 1999; 17:88-90.

10. Cohen SP, Hurley RW, Buckenmaier CC, Kurihara C, Morlando B, Dragovich A. Randomized placebo-controlled study evaluating lateral branch radiofrequency denervation for sacroiliac joint pain. Anesthesiology 2008; 109:279-288.

11. Patel N, Gross A, Brown L, Gekht G. A randomized, placebo-controlled study to assess the efficacy of lateral branch neurotomy for chronic sacroiliac joint pain. Pain Med 2012; 13:383-398.

12. Juch JNS, Maas ET, Ostelo RWJG, Groeneweg JG, Kallewaard J-W, Koes BW, Verhagen AP, van Dongen JM, Huygen FJPM, van Tulder MW. Effect of radiofrequency denervation on pain intensity among patients with chronic low back pain: The mint randomized clinical tri- als. JAMA 2017; 318:68-81.

13. van Tilburg $(W)$, Schuurmans FA, Stronks DL, Groeneweg JG, Huygen FJPM. Randomized sham-controlled double-blind multicenter clinical trial to ascertain the effect of percutaneous radiofrequency treatment for sacroiliac joint pain: Three-month results. Clin J Pain 2016; 32:921-926.

14. Gaenslen FJ. Sacro-iliac arthrodesis: Indications, author's technic and end-results. J Am Med Assoc 1927; 89:2031-2035.

15. Smith-Petersen MN. Arthrodesis of the sacroiliac joint. A new method of approach. J Bone Jt Surg 1921; 3:400-405.

16. Hagen R. Pelvic girdle relaxation from an orthopaedic point of view. Acta Orthop Scand 1974; 45:550-563.

17. Waisbrod H, Krainick JU, Gerbershagen HU. Sacroiliac joint arthrodesis for chronic lower back pain. Arch Orthop Trauma Surg Arch Für Orthop Unf-Chir 1987; 106:238-240.

18. Kibsgård TJ, Røise O, Sudmann E, Stuge B. Pelvic joint fusions in patients with chronic pelvic girdle pain: A 23-year follow-up. Eur Spine J 2013; 22:871-877.

19. Giannikas KA, Khan AM, Karski MT, Maxwell HA. Sacroiliac joint fusion for chronic pain: A simple technique avoiding the use of metalwork. Eur Spine J 2004; 13:253-256.

20. Buchowski JM, Kebaish KM, Sinkov V, Cohen DB, Sieber AN, Kostuik JP. Functional and radiographic outcome of sacroiliac arthrodesis for the disorders of the sacroiliac joint. Spine J 2005; 5:520528; discussion 529.

21. Lorio MP, Polly DW Jr, Ninkovic I, Ledonio CGT, Hallas K, Andersson G. Utilization of minimally invasive surgical approach for sacroiliac joint fusion in surgeon population of ISASS and SMISS membership. Open Orthop J 2014; 8:1-6.

22. Rudolf L. Sacroiliac joint arthrodesisMIS technique with titanium implants: Report of the first 50 patients and outcomes. Open Orthop J 2012; 6:495-502.

23. Cummings J Jr, Capobianco RA. Minimally invasive sacroiliac joint fusion: One-year outcomes in 18 patients. Ann Surg Innov Res 2013; 7:12.

24. Gaetani P, Miotti D, Risso A, Bettaglio R, Bongetta D, Custodi V, Silvani V. Percutaneous arthrodesis of sacro-iliac joint: A pilot study. J Neurosurg Sci 2013; 57:297-301.

25. Sachs D, Capobianco R, Cher D, Holt T, Gundanna M, Graven T, Shamie AN, Cummings J. One-year outcomes after 
minimally invasive sacroiliac joint fusion with a series of triangular implants: A multicenter, patient-level analysis. Med Devices Evid Res 2014; 7:299-304.

26. Ledonio CGT, Polly DW, Swiontkowski MF. Minimally invasive versus open sacroiliac joint fusion: Are they similarly safe and effective? Clin Orthop 2014; 472:1831-1838.

27. Ledonio C, Polly D, Swiontkowski MF, Cummings J. Comparative effectiveness of open versus minimally invasive sacroiliac joint fusion. Med Devices Evid Res 2014; 2014:187-193.

28. Graham Smith A, Capobianco R, Cher D, Rudolf L, Sachs D, Gundanna M, Kleiner J, Mody MG, Shamie AN. Open versus minimally invasive sacroiliac joint fusion: A multi-center comparison of perioperative measures and clinical outcomes. Ann Surg Innov Res 2013; 7:14.

29. Polly DW, Swofford J, Whang PG, Frank C, Glaser JC, Limoni RP, Cher DJ, Wine KD, Sembrano JN; INSITE Study Group. Two-year outcomes from a randomized controlled trial of minimally invasive sacroiliac joint fusion vs. non-surgical management for sacroiliac joint dysfunction. Int J Spine Surg 2016; 10:28.

30. Duhon BS, Bitan F, Lockstadt H, Kovalsky D, Cher D, Hillen T. Triangular titanium implants for minimally invasive sacroiliac joint fusion: 2-year follow-up from a prospective multicenter trial. Int J Spine Surg 2016; 10:13.

31. Sturesson B, Kools D, Pflugmacher R, Gasbarrini A, Prestamburgo D, Dengler J. Six-month outcomes from a randomized controlled trial of minimally invasive SI joint fusion with triangular titanium implants vs. conservative management. Eur Spine ] [Internet] 2016; Available from: http://link.springer.com/ article/10.1007/s00586-016-4599-9

32. Dengler J, Sturesson B, Kools D, Prestamburgo $D$, Cher D, van Eeckhoven E, Erk E, Pflugmacher R, Vajkoczy P, and the iMIA study group. Referred leg pain originating from the sacroiliac joint: 6-month outcomes from the prospective randomized controlled iMIA trial. Acta Neurochir (Wien) 2016; 158:2219-2224.

33. Fairbank JC, Pynsent PB. The Oswestry Disability Index. Spine 2000; 25:29402952; discussion 2952.

34. Fortin JD, Falco FJ. The Fortin finger test: An indicator of sacroiliac pain. Am J Or- thop Belle Mead NJ 1997; 26:477-480.

35. Vleeming A, Albert HB, Östgaard HC, Sturesson B, Stuge B. European guidelines for the diagnosis and treatment of pelvic girdle pain. Eur Spine ] 2008; 17:794-819.

36. Mens JM, Vleeming A, Snijders CJ, Koes BW, Stam HJ. Reliability and validity of the active straight leg raise test in posterior pelvic pain since pregnancy. Spine 2001; 26:1167-1171.

37. EuroQol Group. EuroQol--a new facility for the measurement of health-related quality of life. Health Policy Amst Neth 1990; 16:199-208.

38. Boonen S, Van Meirhaeghe J, Bastian L, Cummings SR, Ranstam J, Tillman JB, Eastell R, Talmadge K, Wardlaw D. Balloon kyphoplasty for the treatment of acute vertebral compression fractures: 2-year results from a randomized trial. J Bone Miner Res 2011; 26:1627-1637.

39. Ranstam J, Turkiewicz A, Boonen S, Van Meirhaeghe J, Bastian L, Wardlaw D. Alternative analyses for handling incomplete follow-up in the intention-to-treat analysis: The randomized controlled trial of balloon kyphoplasty versus nonsurgical care for vertebral compression fracture (FREE). BMC Med Res Methodol 2012; 12:35.

40. Cardenas DD, Nieshoff EC, Suda K, Goto S-I, Sanin L, Kaneko T, Sporn J, Parsons B, Soulsby M, Yang R, Whalen E, Scavone JM, Suzuki MM, Knapp LE. A randomized trial of pregabalin in patients with neuropathic pain due to spinal cord injury. Neurology 2013; 80:533-539.

41. Delmas PD, Ensrud KE, Adachi JD, Harper KD, Sarkar S, Gennari C, Reginster J-Y, Pols HAP, Recker RR, Harris ST, Wu W, Genant HK, Black DM, Eastell R; Mulitple Outcomes of Raloxifene Evaluation Investigators. Efficacy of raloxifene on vertebral fracture risk reduction in postmenopausal women with osteoporosis: Four-year results from a randomized clinical trial. J Clin Endocrinol Metab 2002; 87:3609-3617.

42. Fairbank J, Frost H, Wilson-MacDonald J, Yu L-M, Barker K, Collins R; Spine Stabilisation Trial Group. Randomised controlled trial to compare surgical stabilisation of the lumbar spine with an intensive rehabilitation programme for patients with chronic low back pain: The
MRC spine stabilisation trial. BMJ 2005; 330:1233.

43. Peterson CD, Haas M, Gregory WT. A pilot randomized controlled trial comparing the efficacy of exercise, spinal manipulation, and neuro emotional technique for the treatment of pregnancyrelated low back pain. Chiropr Man Ther 2012; 20:18.

44. Hollis S, Campbell F. What is meant by intention to treat analysis? Survey of published randomised controlled trials. BMJ 1999; 319:670-674.

45. R Core Team (2013). R: A language and environment for statistical computing. [Internet]. Vienna, Austria; available from: http://www.R-project.org/

46. Strömqvist $B$, Fritzell $P$, Hägg $O$, Jönsson B, Sandén B. Swespine: The Swedish spine register. Eur Spine J 2013; 22:953-974.

47. Sachs D, Kovalsky D, Redmond A, Limoni R, Meyer SC, Harvey C, Kondrashov D. Durable intermediate- to long-term outcomes after minimally invasive transiliac sacroiliac joint fusion using triangular titanium implants. Med Devices Auckl NZ 2016; 9:213-222.

48. Rudolf L, Capobianco R. Five-year clinical and radiographic outcomes after minimally invasive sacroiliac joint fusion using triangular implants. Open Orthop J 2014; 8:375-383.

49. Cher DJ, Reckling WC, Capobianco RA. Implant survivorship analysis after minimally invasive sacroiliac joint fusion using the iFuse Implant System. Med Devices Evid Res 2015; 8:485-492.

50. Martin BI, Mirza SK, Comstock BA, Gray DT, Kreuter W, Deyo RA. Reoperation rates following lumbar spine surgery and the influence of spinal fusion procedures. Spine 2007; 32:382-387.

51. Martin BI, Mirza SK, Flum DR, Wickizer TM, Heagerty PJ, Lenkoski AF, Deyo RA. Repeat surgery after lumbar decompression for herniated disc: The quality implications of hospital and surgeon variation. Spine ] 2012; 12:89-97.

52. Stuge B, Laerum E, Kirkesola G, Vøllestad N. The efficacy of a treatment program focusing on specific stabilizing exercises for pelvic girdle pain after pregnancy: A randomized controlled trial. Spine 2004; 29:351-359. 